\title{
Preface to the Fourth Issue of Indian-Pacific Journal of Accounting and Finance
}

I welcome you with most significant pleasure and honour to the Volume 1 Issue 4 of IndianPacific Journal of Accounting and Finance. In this Issue 4, the emphasis is placed on accounting, taxation, business administration, corporate governance and risk management, accounting regulation and financial reporting, and accounting.

In the first paper entitled "Board Characteristics, Corporate Performance and CEO Turnover Decisions: An empirical study of listed Non-financial Companies", Mr Yahya Uthman Abdullahi (Tunku Puteri Intan Safinaz School of Accountancy, Universiti Utara Malaysia), Dr. Rokiah Ishak (Tunku Puteri Intan Safinaz School of Accountancy, Universiti Utara Malaysia) and Dr. Norfaiezah Sawandi (Tunku Puteri Intan Safinaz School of Accountancy, Universiti Utara Malaysia) examine the influence of board characteristics and corporate performance on CEO turnover decisions using a sample of 144 firms from non-financial companies listed on the Nigerian Stock exchange between the periods of 2011 to 2015. The study adopts agency and resource dependency theories to support its objectives and applies a logistic regression statistical technique to analyse the results. The results show that board nominating committee has a significant positive relationship with CEO turnover and board gender diversity has a negative influence on CEO turnover. Also, the study also finds that poor corporate performance leads to CEO turnover. In concurring with the findings, the study suggests to the government to enact legislation on gender quota for more women appointment on the board of the corporation to better the performance of the firm, and as well to enhance the monitoring role of the board.

In the second paper with the caption "Factors affecting the productivity of IRBM Field Tax Auditor: A Case Study in Malaysia", Mr Sabin Samitah (Tunku Puteri Intan Safinaz School of Accountancy, Universiti Utara Malaysia), Prof Dr Kamil Md Idris (Tunku Puteri Intan Safinaz School of Accountancy, Universiti Utara Malaysia) and Dr Saliza Abdul Aziz (Tunku Puteri Intan Safinaz School of Accountancy, Universiti Utara Malaysia) explore the idea of factors affecting the productivity of field tax auditors in the Inland Revenue Board of Malaysia (IRBM). This study is significant because IRBM has not yet implemented a systematic method of deploying officers to the field tax audit unit throughout Malaysia. The factors identified could be used as a reference in designing future human development programme in IRBM with particular emphasis on field tax auditors. Several variables have been defined, which broadly classified into individual characteristics and external factors. Data for the analysis are sourced from IRBM's internal database, unpublished records and direct questionnaire of all respondents engaged in the field audit in Klang Valley. The proposed idea would analyse the relationship between auditors' productivity and various variables based on the initial assumption that all variables are influencing the productivity through direct impact. This is, however, merely an initial expectation and subject to further data analysis once the data collection is implemented and completed.

In the third paper with the title "Knowledge sharing and barriers in Organisations: A conceptual paper on Knowledge-Management Strategy", Mr Saravanan Nadason (School of Business Management, Universiti Utara Malaysia), Associate Prof Dr Ram Al-Jaffri Saad (Tunku Puteri Intan Safinaz School of Accountancy, Universiti Utara Malaysia) and Dr Aidi Ahmi (Tunku Puteri Intan Safinaz School of Accountancy, Universiti Utara 
Malaysia) investigates the barriers that give impact towards the knowledge sharing among individuals in organisations. Knowledge sharing becomes the significant part of many organisations' knowledge-management strategy. Even though the knowledge sharing is signifying practice for organisations' competitiveness directly and market performance indirectly, several barriers make it difficult for knowledge management to achieve the goals and deliver a positive return on investment (ROI). The barriers were identified through literature reviews. The findings of previous studies revealed that several factors affect the knowledge sharing in organisations. This paper provides the analysis of significant factors that influence knowledge sharing in organisations, which comprise the individuals, culture, technology and organisation.

In the fourth paper entitled "Ownership Structure and Earnings Management of listed Conglomerates in Nigeria", Dr Musa Adeiza Farouk (Department of Accounting, Ahmadu Bello University) and Dr Nafiu Muhammad Bashir (Department of Business Administration, Ahmadu Bello University) examine the effect of ownership structure on earnings management of listed conglomerates in Nigeria. Ownership structure is represented with managerial ownership, institutional ownership, block ownership and foreign ownership, while earnings management is measured using modified Jones model by Dechow, Sloan and Sweeney (1995). Data were obtained from the six listed conglomerates on the Nigerian Stock Exchange covering the period 2008-2014 through their annual reports and accounts. The findings show that managerial ownership and ownership concentration have a significant and adverse effect on earnings management of listed conglomerates in Nigeria, while foreign ownership recorded positive and significant impact on earnings management of firms, institutional ownership was however reported to have an insignificant but negative influence on earnings management. The study, therefore, recommends that management should be encouraged to have more interest through shares in the organisation as it enables them to have more sense of belonging, which in turn will help mitigate their opportunistic tendencies. Also, the institutional ownership should be improved upon through allotment of more shares as these categories of investors are well informed and could be more vigilant over their stake in the organisation thereby performing monitoring role to mitigate earnings management.

In the fifth paper with the title "Corporate Governance Structure and Firm Performance: A Case Study of Malaysian University Holdings Companies", Prof Dr Wan Nordin Wan Hussina (Othman Yeop Abdullah Graduate, College of Business, Universiti Utara Malaysia), Dr. Norfaiezah Sawandi (Tunku Puteri Intan Safinaz School of Accountancy, College of Business, Universiti Utara Malaysia), and Dr Hasnah Shaari (Tunku Puteri Intan Safinaz School of Accountancy, College of Business, Universiti Utara Malaysia) analyse the corporate governance structure and performance of Malaysian public university holding companies from 2010 to 2014 . The sample comprises eight public university holding companies. Data were obtained by using three methods, namely: survey, semi-structured interview, and documentation review. The board structure and board sub-committees practices of these case organisations were evaluated against the best practice recommendation of (i) the Malaysian Code on Corporate Governance (MCCG) 2012, (ii) the Green Book 2006, and (iii) other relevant acts. The firm performance is measured using four indicators which are sales, profit before tax, net profit margin and return on equity. Overall, their study finds that the practice and structure of corporate governance of the holding companies are excellent. However, their study reveals noncompliance by companies about certain aspects of the recommendations of Malaysian Code on Corporate Governance 2012 (MCCG) and the Green Book. The study also observed that the practice of governance between the university companies is not uniform. The findings provide an insight into the competence of the ministry of higher education as the shareholder to improve the monitoring of the public university holding companies. 
As you read through this Vol. 1 Issue 4 of IPJAF, I would like to reiterate that the success of the journal depends on your active participation and those of your colleagues and friends through submission of high-quality articles within the journal scope for review and publication.

I acknowledge your support as we endeavour to make IPJAF the most authoritative journal on accounting and finance for the community of academic, professional, industry, society and government.

\section{Oluwatoyin Muse Johnson Popoola, PhD}

Editor-in-Chief

popoola@omjpalpha.com 